\title{
Ендометріоз як хірургічна проблема: діагностично-лікувальна тактика, невирішені питання
}

\begin{abstract}
Мета роботи: опис нетипових клінічних випадків та поширення їх серед медичної спільноти, що сприятиме накопиченню мультицентрового клінічного досвіду та ляже в основу розробки ефективних алгоритмів менеджменту нетипових проявів екстрагенітального ендометріозу.

Матеріали і методи. Проведено комплексне дослідження 12 жінок віком 24-42 роки. Окрім загальноприйнятих клінічних лабораторних досліджень, проводили рентгенологічне, сонографічне обстеження та комп’ютерну томографію органів черевної порожнини.

Результати досліджень та їх обговорення. Наведені приклади клінічних випадків показують, що ендометріоз не можна вважати лише гінекологічним захворюванням, як у діагностичному, так і в лікувальному процесі він виходить далеко за межі гінекологічної спеціальності, а лікування його потребує нетрадиційної тактики. Найчастіше екстрагенітальні форми ендометріозу локалізуються в ділянці кишечника та післяопераційного рубця. Поява клінічних проявів дискоморту та пухлиноподібного утвору в ділянці післяопераційної рани є головними клінічними ознаками ендометріозу рубця. Основним клінічним проявом ендометріозу кишечника є розвиток кишкової непрохідності. За наявності операцій на матці в анамнезі треба проводити дифдіагностику з екстрагенітальним ендометріозом.

Медикаментозна терапія у хворих на ендометріоз не може бути методом вибору. Поширення вогнищ захворювання потребує індивідуального вибору та оптимального поєднання хірургічного та медикаментозного компонентів лікування, розширює тактичний арсенал лікаря, підвищує ефективність лікування, що покращує прогноз хвороби.
\end{abstract}

Ключові слова: екстрагенітальний ендометріоз; післяопераційний рубець; лікування.

Постановка проблеми і аналіз останніх досліджень та публікацій. У світі нараховують приблизно 176 мільйонів жінок, які страждають від хронічного тазового болю, що значно знижує якість їх життя [1, 2]. Ендометріоз належить до одного з найбільш поширених доброякісних захворювань жіночої репродуктивної системи та посідає третє місце у структурі гінекологічної захворюваності після запальних процесів та лейоміоми матки [3]. Він є причиною не лише больового синдрому в ділянці малого таза, а й безпліддя. Дані багатьох досліджень вказують, що 1 із 10 жінок впродовж репродуктивного періоду має клінічні появи цього захворювання $[4,5]$.

Етіологічні фактори ендометріозу досить складні та досі недостатньо вивчені. Сучасні наукові уявлення про його патогенез базуються на трьох основних теоріях: ретроградний закид менструальної крові, целомічна метаплазія та теорія індукції. Певну роль у розвитку ендометріозу відіграють генетика та епігенетика [6]. Проте наукові дослідження останніх років вказують на важливу патофізіологічну роль окисного стресу, який визначається як дисбаланс між активними формами кисню (АФК) та антиоксидантами, що спричиняє загальну запальну реакцію в порожнині очеревини $[7,8]$.
Типовими симптоми ендометріозу є болючі менструації, болючі овуляції, біль під час або після статевого акту, значні кров'янисті виділення під час менструації, хронічний тазовий біль, втома, безпліддя, які негативно впливають як на загальний фізичний стан, так і на психічну діяльність та соціальну сферу життя. Однак якщо генітальні форми ендометріозу мають типову клінічну картину, то діагностика ектрагенітальних форм залишається надскладним завданням і потребує залучення як сучасних методів візуалізації для його діагностики, так і мультидисциплінарного підходу до вибору терапевтичної тактики [911]. Опис нетипових клінічних випадків та поширення їх серед медичної спільноти сприятиме накопиченню мультицентрового клінічного досвіду та ляже в основу розробки ефективних алгоритмів менеджменту нетипових проявів даного захворювання, що і стало метою нашої роботи.

Матеріали і методи. Проведено комплексне дослідження 12 жінок віком 24-42 роки. Окрім загальноприйнятих клінічних лабораторних досліджень, проводили рентгенологічне, сонографічне обстеження та комп'ютерну томографію органів черевної порожнини. Паралельно визначали ступінь інтоксикаційного синдрому - лейкоци- 
тарний індекс інтоксикації (ЛІІ), неспецифічну резистентність організму за допомогою паличкоядерно-лімфоцитарного індексу (ПЛІ) та онкомаркери. Медикаментозне терапію застосовували 3 метою профілактики рецидивів після операційного лікування.

Результати досліджень та їх обговорення. Згідно з МКХ 10 у 3 хворих спостерігали ендометріоз у стадії N80.5 - ендометріоз кишки, в 9 випадків N80.6 - ендометріоз рубця шкіри. Останнім під загальним обезболюванням проведено висічення ендометріозу післяопераційного рубця передньої черевної стінки.

Наводимо клінічний приклад.

Хвора К., 34 роки звернулась у хірургічну клініку зі скаргами на наявність болючого утвору в правій паховій ділянці. Хворіє впродовж п'яти років, коли спочатку виник біль справа внизу живота, який турбував під час менструації та інтенсивність якого зростала з роками. Через якийсь час у хворої з'явився утвір у правій паховій ділянці в проекції післяопераційного рубця, який з часом почав збільшуватися. Скарги пацієнтка пов'язує з тим, що в анамнезі під час вагітності їй виконали лапаротомію, холецистектомію, зовнішнє дренування ходедоха, сальникової сумки із приводу гострого біліарного панкреатиту, кесарів розтин. Через 4 роки - повторний кесарів розтин, діти здорові.

Проведено обстеження: загальний стан - задовільний; язик - вологий, чистий. Гемодинамічні показники - в межах норми. Живіт: правильної форми, симетричний, нездутий, м'який. Аускультативно - перистальтичні кишкові звуки ритмічні, середніми хвилями. Фізіологічні виділення в нормі. В правій здухвинній ділянці під рубцем у місці дренування черевної порожнини щільний подовгувастий утвір 14,0×3,0 см, рухливий, малоболючий, шкіра над ним незмінена.

Загальний аналіз крові: еритроцитів 4,32×1012/ л, гемоглобін - 146 г/л, лейкоцитів - 5,8×10\% л, паличкоядерних нейтрофілів - $9 \%$, сегментоядерних $54 \%$, лімфоцитів - 34 \%, моноцитів - 3 \%. ЛІІ 1,95 од., ПЛІ - 0,27 од. Біохімічний аналіз крові - в межах норми.

При сонографічному досліджені в товщі передньої черевної стінки справа підшкірно на поверхні прямого м'яза живота утвір - вузол 30×143×29 мм. Показники периферійної крові, лейкоцитарний індекс інтоксикації і стан неспецифічної резистентності організму, як правило, не були порушені.

Під комбінованим внутрішньовенним знеболенням проведено висічення пухлиноподібного утвору з використанням електроскальпеля, що вважається поряд 3 іншими методами однаково високоефектив- ним [3]. Патологогістологічне заключення: екстрагенітальний ендометріоз пористої структури.

Заключний клінічний діагноз - екстрагенітальний ендометріоз післяопераційного рубця передньої черевної стінки.

Перебіг післяопераційного періоду без ускладнень. Післяопераційна рана загоїлась первинним натягом. Після операції хворій призначено впродовж 6 місяців аналоги гонадотропін-рилізинг-гормону за загальноприйнятою схемою. При огляді через 7 років рецидиву захворювання не виявлено.

У пацієнтки комбіноване використання хірургічного і медикаментозного лікування при ендометріозі післяопераційного рубця було ефективним та доцільним комплексом.

При залученні до патологічного процесу, крім матки, парієтальної очеревини малого таза і сусідніх органів в IV стадії захворювання під внутрішньовенним комбінованим наркозом із ШВЛ оперовано 3 хворих. Наводимо клінічний випадок.

Хвора 3., 44 роки госпіталізована в хірургічне відділення на 10 день після операції зі скаргами на переймоподібний біль та здуття живота, гази не відходять, затримка випорожнень.

У 2007 р. хворій була виконана лапароскопія, пластика маткових труб. В 2010 р. - лапаротомія, суправагінальна ампутація матки з частковою резекцією правого яєчника. 27.05.2019 р. - лапаротомія, видалення лівих придатків матки, роз'єднання злук черевної порожнини, резекція сальника, дренування черевної порожнини з приводу розриву ендометріоїдної кісти лівого яєчника, спайкової хвороби очеревини.

Патогістологічне дослідження. В препаратах виявляють фімбрії маткової труби та м'які тканини, що оточують маткову трубу, та шматочки сальника з наявністю в усіх м'яких тканинах розлитого гнійного запалення з формуванням на деяких ділянках абсцесів, що містять некротичні маси з ознаками каріорексису, деякі абсцеси містять багато еозинофілів. Такі зміни відповідають гнійному аднекситу, оментиту та перитоніту інфекційної природи. У складі інфільтрату відсутні епітеліоїдні макрофаги та гігантські клітини, тому туберкульозна етіологія виключається.

У зв'язку з виникненням інфільтрату в черевній порожнині, який супроводжувався явищами кишкової непрохідності, хвору перевели в хірургічне відділення.

Загальний стан хворої середнього ступеня тяжкості. Пульс - 88 ударів за хвилину, ритмічний задовільний, артеріальний тиск - 125 і 75 мм рт. ст. Язик вологий, обкладений нашаруванням білого кольору. Живіт здутий, симетричний. Передня черевна стінка бере участь у диханні. При пальпації 
- передня черевна стінка напружена, ввесь живіт болючий. Перкуторно - тимпаніт; аускультація - кишкові перистальтичні звуки різко ослаблені, поодинокі. Симптоми подразнення очеревини від’ємні; симптом плескоту - від’ємний.

Загальний аналіз крові: еритроцитів 4,25×1012/ л, гемоглобін - 125 г/л, лейкоцитів - 14,2×10\% л, паличкоядерних нейтрофілів - 13 \%, сегментоядерних - 77 \%, лімфоцитів - 6 \%, моноцитів - 3 \%. ЛІІ - 5,72 од., ПЛІ - 2,17 од. Біохімічний аналіз крові - в межах норми.

При рентгенологічному досліджені органів черевної порожнини виявлено рівні рідини в епігастрії та в підребер’ї, вільного газу не виявлено.

При сонографічному дослідженні органів черевної порожнини по бокових каналах - під печінкою асцитична рідина близько 150-200 мл, над селезінкою скупчення рідини 180 мл. В обох легеневих синусах по 40-50 мл однорідної рідини. Перистальтика тонкої кишки порушена за рахунок інфільтрації сальника в лівій клубовій ділянці з розширенням петель до 25 мм, визначається гаустрація товстої кишки. Стаз шлунка. Вміст у тонкій кишці стазований, маятникоподібний рух хімусу не визначається. Петлі тонкої кишки розширені до 35 мм, висота гаустр - 25 мм.

Проведено комп'ютерну томографію органів черевної порожнини із внутрішньовенним контрастним підсиленням “Ультравіст-370 ” 100 мл.

Висновок: асцит. Інфільтрація великого сальника. Вільне повітря в проекції малого таза. Об’ ємний утвір правого яєчника. Інфільтативне потовщення стінок поперечноободової кишки. Ознаки тонкокишкової непрохідності. Правобічна нижньочасточкова плевропневмонія. Двобічний гідроторакс.

Проведено дослідження онкомаркерів яєчників. Отримано такі результати: ранній онкомаркер яєчників НЕ-4 - 65,66 пмоль/л; онкомаркер яєчників (CA-125) (кров) - 391,8 Од/мл; індекс ROMA (кров) - 15,9\%.

Після комплексного обстеження хворій встановлено клінічний діагноз: екстрагенітальний ендометріоз у стадії N80.5 - ендометріоз кишки; інфільтрат черевної порожнини; гостра непрохідність тонкої кишки, в стадії субкомпенсації; (операційне втручання 27.05.2019 - видалення лівого яєчника; резекція частини великого сальника; роз’єднання спайок і дренування черевної порожнини). Правобічна нижньочасточкова плевропневмонія, двобічний гідроторакс. Призначено лікування: декомпресія шлунка, антибіотикотерапія, спазмолітична терапія, девульсія сфінктера прямої кишки та стимулюючі мікроклізми, парентеральна інтенсивна терапія. Введено препарат пролонгованої дії - Золадекс ${ }^{\circledR}$ 3,6 мг.

Після проведеної інтенсивної терапії стан хворої поступово покращився. ЛІІ - 0,40 од., ПЛІ 0,25 од.. Моторно-евакуаторна функція травного каналу відновилась і пацієнтку в задовільному стані виписали на амбулаторне лікування під спостереження гінеколога.

В одному випадку проведено резекцію петлі тонкої кишки з формуванням ентеро-ентероанастомозу, в іншому - проведено відділення ректосигмоїдного кута товстої кишки від матки з приводу непрохідності товстої кишки В останньому випадку проведення радикальної операції було недоцільним через наявність супутньої патології - фібромастопатії лівої молочної залози, з приводу якої хвора оперована через 6 місяців. Хворим призначали супутню гормональну терапію.

Наведені приклади клінічних випадків показують, що ендометріоз не можна вважати лише гінекологічним захворюванням як у діагностичному, так і в лікувальному процесі, він виходить далеко за межі гінекологічної спеціальності, а його лікування потребує нетрадиційної тактики.

Висновки. Хірургічне лікування ендометріозу в IV стадії перебігу, розповсюдженому процесі цього захворювання і виникненні ускладнень із сторони інших органів черевної порожнини, повинно розглядатися як основний метод лікування. Медикаментозна терапія у хворих на ендометріоз не може бути методом вибору. Поширення вогнищ захворювання потребує індивідуального вибору та оптимального поєднання хірургічного та медикаментозного компонентів лікування, розширює тактичний арсенал лікаря, підвищує ефективність лікування, що покращує прогноз хвороби.

\section{СПИСОК ЛІТЕРАТУРИ}

1. Запорожан В. М. Національний консенсус щодо ведення пацієнток із ендометріозом / В. М. Запорожан, Т. Ф. Татарчук, В. В. Камінський // Репродуктивна ендокринологія. 2015. - № 24. - С. 7-12.

2. Al-Quorain S. A. Primary umbilical endometriosis: case report with literature review / S. A. Al-Quorain, T. A. Al-Yahya // Saudi J. Med. Med. Sci. - 2017. - Vol. 5 (1). - P. 74-76.

3. Boesgaard-Kjer D. Primary umbilical endometriosis (PUE)/

D. Boesgaard-Kjer, D. Boesgaard-Kjer, J. J. Kjer // Eur. J. Obstet. Gynecol. Reprod. Biol. - 2017. - Vol. 209. - P. 44-45.

4. Endometriosis and assisted reproductive technology: a review article / A. Ajayi, V. Ajayi, I. Oyetunji [et al.] // Med. Clin. Rev. 2017. - Vol. 3. - P. 1. DOI: 10.21767/2471-299X.1000046.

5. Oxidative stress and endometriosis: a systematic review of the literature / G. Scutiero, P. Iannone, G. Bernardi [et al.] / Oxid. Med. Cell. Longev. - 2017. - Vol. 2017. - P. 7265238. 
DOI: $10.1155 / 2017 / 7265238$.

6. Multimodality imaging and clinicopathologic assessment of abdominal wall endometriosis: knocking down the enigma / A. Jaramillo-Cardoso, P. Balcacer, A. Garces-Descovich [et al.] // Abdom. Radiol. (NY). - 2020. - Vol. 45 (6). - P. 1800-1812.

7. Bowel endometriosis: diagnosis and management / C. Nezhat, A. Li, R. Falik [et al.] // Am. J. Obstet. Gynecol. - 2018. Vol. 218 (6). - P. 549-562.

8. The role of oxidative stress and membrane transport systems during endometriosis: a fresh look at a busy corner / S. G. Vitale, S. Capriglione, I. Peterlunger [et al.] // Oxid. Med. Cell. Longev. - 2018. - Vol. 2018. - P. 7924021. DOI: 10.1155/2018/7924021. 9. Prevention of the recurrence of symptom and lesions after conservative surgery for endometriosis / K. Koga, M. Takamura, T. Fu- jii, Y. Osuga // Fertil. Steril. - 2015. - Vol. 104 (4). - P. 793-801. 10. Atypical sites of deeply infiltrative endometriosis: clinical characteristics and imaging findings / L. P. Chamié, D. M. F. R. Ribeiro, D. A. Tiferes [et al.] // Radiographics. - 2018. - Vol. 38 (1). - P. 309-328.

11. Особливості клінічної характеристики пацієнток з генітальним ендометріозом на тлі гіпотиреозу в періопераційному періоді / Т. А. Струк, О. А. Гордійчук, О. А. Нікітіна, О. О. Литвак // Клініч. та профілакт. медицина. - 2020. - № 1 (11). - C. $40-50$.

12. What abdominal radiologists should know about extragenital endometriosis-associated neuropathy / J. P. Moura Filho, R. V. Leão, N. Horvat [et al.] // Abdom. Radiol. (NY). - 2020. Vol. 45 (6). - P. 1818-1828.

\section{REFERENCES}

1. Zaporozhan, V.M., Tatarchuk, T.F., \& Kaminskyi, (2015). Natsionalnyi konsensus shchodo vedennia patsiientok iz endometriozom [National consensus on the management of patients with endometriosis]. Reproduktyvna endokrynolohiia - Reproductive Endocrinology, 24, 7-12 [in Ukrainian].

2. Al-Quorain, S.A., \& Al-Yahya, T.A. (2017). Primary umbilical endometriosis: case report with literature review. Saudi J. Med. Med. Sci., 5 (1), 74-76.

3. Boesgaard-Kjer, D., Boesgaard-Kjer, D., \& Kjer, J.J. (2017). Primary umbilical endometriosis (PUE). Eur. J. Obstet. Gynecol. Reprod. Biol., 209, 44-45.

4. Ajayi, A., Ajayi, V., Oyetunji, I., Biobaku, O., Aikhuele, H., Atiba, A., \& Afolabi B.M. (2017). Endometriosis and assisted reproductive technology: a review article. Med. Clin. Rev., 3, 1. DOI: 10.21767/2471-299X.1000046.

5. Scutiero, G., Iannone, P., Bernardi, G., Bonaccorsi, G., Spadaro, S., Volta, C.A., ..., \& Nappi, L. (2017). Oxidative stress and endometriosis: a systematic review of the literature. Oxid. Med. Cell. Longev., 2017, 7265238. DOI: 10.1155/2017/7265238.

6. Jaramillo-Cardoso, A., Balcacer, P., Garces-Descovich, A., Beker, K., Roth, E., Glickman, J., \& Mortele, K.J. (2020). Multimodality imaging and clinicopathologic assessment of abdominal wall endometriosis: knocking down the enigma. Abdom. Radiol. (NY), 45 (6), 1800-1812.

7. Nezhat, C., Li, A., Falik, R., Copeland, D., Razavi, G.,

Shakib, A., ..., \& Nezhat, F. (2018). Bowel endometriosis: diagnosis and management. Am. J. Obstet. Gynecol., 218 (6), 549-562. 8. Vitale, S.G., Capriglione, S., Peterlunger, I., La Rosa, V.L., Vitagliano, A., Noventa, M., ..., \& Zito, G. (2018.). The role of oxidative stress and membrane transport systems during endometriosis: a fresh look at a busy corner. Oxid. Med. Cell. Longev., 2018, 7924021. DOI: 10.1155/2018/7924021.

9. Koga, K., Takamura, M., Fujii, T., \& Osuga, Y. (2015). Prevention of the recurrence of symptom and lesions after conservative surgery for endometriosis. Fertil. Steril., 104 (4), 793-801.

10. Chamié, L.P., Ribeiro, D.M.F.R., Tiferes, D.A., Macedo Neto, A.C., \& Serafini, P.C. (2018). Atypical sites of deeply infiltrative endometriosis: clinical characteristics and imaging findings. Radiographics, 38 (1), 309-328.

11. Struk, T., Gordeichuk, O., Nikitina, O., \& Lytvak, O. (2020). Osoblyvosti klinichnoi kharakterystyky patsiientok z henitalnym endometriozom na tli hipotyreozu $\mathrm{v}$ perioperatsiinomu periodi [The peculiarities of perioperative clinical characteristics of patients with genital endometriosis associated with hypothyrosis]. Klinichna ta profilaktychna medytsyna - Clinical Medicine, 1 (11), 40-50 [in Ukrainian].

12. Moura Filho, J.P., Leão, R.V., Horvat, N., Helito, P.V.P., Amaral, D.T., Viana, P.C.C., ..., \& Bordalo-Rodrigues, M. (2020). What abdominal radiologists should know about extragenital endometriosis-associated neuropathy. Abdom. Radiol. (NY), 45 (6), 1818-1828.

Отримано 03.07.2020

\section{V. BENEDYKT ${ }^{1}$, S. M. HERYAK ${ }^{1}$, O. M. HUSAK ${ }^{2}$, N. V. PETRENKO ${ }^{1}$, I. V. KORDA ${ }^{1}$}

I. Horbachevsky Ternopil National Medical University ${ }^{1}$

Ternopil University Hospital ${ }^{2}$

\section{ENDOMETRIOSIS AS A SURGICAL PROBLEM: DIAGNOSTIC AND TREATMENT, OUTSTANDING ISSUES}

The aim of the work: to describe atypical clinical cases and disseminate them among the medical community, which will contribute to the accumulation of multicenter clinical experience and will form the basis for the development of effective management algorithms for atypical manifestations of extragenital endometriosis.

Materials and Methods. A comprehensive study of 12 women aged 24-42 years was conducted. In addition to conventional clinical laboratory tests, X-ray, sonographic examination and computed tomography of the abdominal organs were performed.

Results and Discussion. These examples of clinical cases show that endometriosis can not be considered only a gynecological disease. Both in the diagnostic and in the treatment process, it goes far beyond the gynecological specialty, and its treatment requires nontraditional tactics. Most often, extragenital forms of endometriosis are localized in the intestine and postoperative scar. The appearance 
of clinical manifestations of discomortation and tumor-like formation in the area of the postoperative wound are the leading clinical signs of scar endometriosis. The main clinical manifestation of intestinal endometriosis is the development of intestinal obstruction. Drug therapy in patients with endometriosis may not be the method of choice.

The spread of foci of the disease requires individual choice and the optimal combination of surgical and medical components of treatment, expands the tactical arsenal of the doctor, increases the effectiveness of treatment, which improves the prognosis.

Key words: extragenital endometriosis; postoperative scar; treatment.

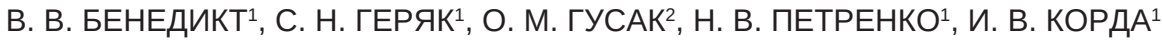

Тернопольский национальный медицинский университет имени И. Я. Горбачевского МОЗ Украины ${ }^{1}$

Тернопольская университетская больница

\title{
ЭНДОМЕТРИОЗ КАК ХИРУРГИЧЕСКАЯ ПРОБЛЕМА: ДИАГНОСТИЧЕСКАЯ И ЛЕЧЕБНАЯ ТАКТИКА, НЕРЕШЕННЫЕ ВОПРОСЫ
}

Цель работы: описание нетипичных клинических случаев и распространение их среди медицинского сообщества, что будет способствовать накоплению мультицентрового клинического опыта и ляжет в основу разработки эффективных алгоритмов управления нетипичных проявлений экстрагенитального эндометриоза.

Материалы и методы. Проведено комплексное исследование 12 женщин в возрасте 24-42 года. Кроме общепринятых клинических лабораторных исследований, проводили рентгенологическое, сонографическое обследование и компьютерную томографию органов брюшной полости.

Результаты исследований и их обсуждения. Приведенные примеры клинических случаев показывают, что эндометриоз нельзя считать лишь гинекологическим заболеванием. Как в диагностическом, так и в лечебном процессе он выходит за рамки гинекологической специальности, а его лечение требует нетрадиционной тактики. Чаще всего экстрагенитальные формы эндометриоза локализируются в области кишечника и послеоперационного рубца. Появление клинических проявлений дискоморта и опухолевидного образования в области послеоперационной раны являются ведущими клиническими признаками эндометриоза рубца. Основным клиническим проявлением эндометриоза кишечника является развитие кишечной непроходимости. Медикаментозная терапия у больных эндометриозом не может быть методом выбора. Распространение очагов заболевания требует индивидуального подхода и оптимального сочетания хирургического и медикаментозного компонентов лечения, расширяет тактический арсенал врача, повышает эффективность лечения, улучшает прогноз заболевания.

Ключевые слова: экстрагенитальный эндометриоз; послеоперационный рубец; лечение. 